\title{
Profile of Students' Problem Solving Skills and the Implementation of Assisted Guided Inquiry Model in Senior High School
}

\author{
M Cindikia ${ }^{1}$, H R Achmadi ${ }^{2}$, B K Prahani ${ }^{3}$, S Mahtari ${ }^{4}$ \\ 1,2,3 Department of Physics, Universitas Negeri Surabaya, Surabaya 60231, Indonesia \\ ${ }^{4}$ Department of Physics Education, Universitas Lambung Mangkurat, Banjarmasin 70123, Indonesia
}

\begin{abstract}
Article Info
Article history:

Received March 30, 2020

Revised April 22, 2020

Accepted April 24, 2020

Keywords:

Guided Inquiry

$\mathrm{PhET}$

Problem Solving Skills

Senior High School
\end{abstract}

\begin{abstract}
The purpose of this research to analyze profile students' problem solving skill and the implementation of assisted guided inquiry at senior high school. The type of research is used the preliminary research method with data collection techniques such as tests and questionnaires. The data are obtained, analyzed descriptively qualitatively. The results of this study show that only a few students can work on the material using problem-solving strategies (AAssessing the problem (identifying principles to be used in problemsolving), C-create a drawing (translating words in the form of pictures containing about problem-solving instructions), Cconceptualize strategy (outlining the steps that will be used in solving the problem), E-executing the solution (applying the formula to solve the problem by the steps) and finally S-scrutinize the result (giving a level of confidence and give a reason) in solving dynamic electricity problems. Totally of the students, five students had low problem-solving skills, and 25 students who had moderate problemsolving skills. Totally of the students, five students had low problemsolving skills, and 25 students who had moderate problem-solving skills. The lowest problem-solving strategy value is at point $S$ (scrutinize the result). Implementation of learning models provided is not ideal so that it causes students to be less active so that problemsolving skills are lacking and no laboratory supports the learning process. Students are not introduced to the existence of a virtual laboratory $(\mathrm{PhET})$ as a laboratory replacement. So to improve students' problem-solving skills required appropriate learning methods.
\end{abstract}

\section{INTRODUCTION}

According to Saparini et al. (2018), physics is one of the natural sciences that studies phenomena that occur in nature. Physics is a branch that is formed through a scientific process that must be taught to students so that students have a meaningful learning experience. Besides, there are two physical properties, namely as a product and as a process. Physics as a product by illustrating the products produced in the form of facts, concepts, theories, principles, and laws. Physics as a process is students expected to be able to master the basic skills used by scientists in scientific work. So learning physics is not always about facts, principles, legal theories, concepts but also develops scientific skills. Scientific skills are obtained through the classroom using teaching and learning methods that help students through laboratory practice. The implementation of physics learning is still dominated by teachers, which causes passive learners in teaching and learning activities (Hamid, 2011).

Good learning to support the success of educational goals is to meet the elements of good learning by taking into account several elements, including student learning, teaching 
teachers, teaching materials, and the relationship between teachers and students. Active students in learning are one of the most important things in learning physics. According to Suparno (2010), teachers are directed to help and encourage students to be able to learn physics independently.

Learning is a human activity to achieve competence, skills, and attitudes. The purpose of learning is so that humans can get information, knowledge from experiences that have been obtained so that humans can have new things obtained from before not possessed by humans. In the learning process, two factors play an important role, namely teachers and students. To be successful in the learning process, the teacher must play an active role in motivating students and providing the experience. According to Putri et al. (2016), an increase and balance between attitudes, skills, and knowledge competencies is an orientation in Curriculum 2013. Learning that is based on mastery of competencies is a teaching and learning activity that is directed to give knowledge, attitudes, and skills to students to do something, namely a set of intelligence actions in the form of skills, determination, and the full success of responsibilities that must be had to do the tasks given (Majid, 2014).

According to Gok (2011), the main goal of learning is problem-solving skills. Because according to Bogard et al. (2013), problem-solving skills are cognitive activities in the learning process. Problem-solving skills related to aspects of thinking and the ability to reason (Chang, 2010). Problem-solving skills are also needed in building reasoning based on observations and data used to test hypotheses, solve complex problems, represent mathematical equations by using the relationship of results before and after the hypotheses are tested, and be able to work in groups well (Sitika et al., 2015). According to Markawi (2013), problem-solving skills are also needed in sharpening the ability to think through a collection of facts, analysis of information or knowledge, and compile various alternatives, effective resolution strategies. According to Teodorescu et al. (2013) problem solving using the GW-ACCES strategy with problem-solving steps consisting of (1) Assessing the problem (identifying the principles of the problem), (2) Create a drawing (translating words in the form of pictures that contain instructions for solving the problem), (3) Conceptualize the strategy (outlining the steps that will be used to solve the problem), (4) Execute the solution (apply the formula to solve the problem), and (5) Scrutinize the result (level of confidence in the answer).

Based on the results of the pre-research, it was attended by 30 students by working on three problem descriptions and questionnaires on dynamic electrical material by paying attention to problem-solving problems. On the questions given a percentage average of 1.94 students were able to explain the theory used in working on the problem, 2.8 students were able to draw or change the questions in written form, 1.90 students were able to find the steps or concepts used, 1.78 students were able to apply the formula. In problem-solving, there are still many students who look confused, especially in determining the theory used in solving problems and applying formulas, students also still do not understand the lessons about dynamic electricity so that in the process of the process, many are still assisted by subject teachers. The questionnaire consists of 4 questions where of the four questions for numbers 1 and 2 students fill in with the answer "yes" because, according to problemsolving, is very important in solving problems in physics. However, for numbers 3 and 4, students fill in with no answers because they did not do the practice and did not know about the virtual lab (PhET). So from the description above, it can be concluded that problemsolving skills in students are still low. The purpose of this research to analyze profile students' problem solving skill and the implementation of assisted guided inquiry at senior high school. 


\section{RESEARCH METHOD}

This preliminary research is descriptive and it does not to test a hypothesis. The results of this study are used to consider developing learning methods that can improve students' problem-solving abilities. This research was conducted at SMAN 1 Driyorejo, Gresik (Senior High School in Indonesia), with a total of 30 students. The data collection method in this study used teacher interviews, tests, and questionnaires distributed to students. The instruments used in this study were teacher interview sheets, student interview sheets and question test sheets containing three questions with dynamic electric material. Answer sheets containing five completion indicators (A-C-C-E-S), and student questionnaire sheets. The data analysis method used is to use descriptive variable analysis. The aim is to explain and describe the facts and conditions that occur at school through the data obtained. The results are presented in the form of graphic interpretation of problem-solving skills in working on problems divided into three categories, namely low, medium, and high.

\section{RESULTS AND DISCUSSION}

The results of this study aim to analyze the physics problem-solving skills, especially in dynamic electric material. This study uses a test given to students consisting of 3 essay questions that need answers in the form of a description. The answer sheets that have been provided are equipped with indicators of problem-solving skills (A-C-C-E-S) where students are asked to enter answers following predetermined indicators. In addition to tests, questionnaires were also given, which consisted of 4 questions about students' experiences in learning physics at school, problem-solving skills, experience of experimenting and the use of virtual laboratories (PhET).

\section{Based on Tests}

Based on data obtained from 3 questions given to 30 students, it was rated in 3 categories, namely logical, systematic, and complete. If students answer according to the group (complete, logical, and systematic), the value obtained is 3 points. If students answer only two categories (logical and systematic or complete and systematic or logical and complete), the value obtained by students is 2 points. Moreover, if students only answer 1 group, the value obtained by students is 1 point, and if the answer is wrong or does not meet all three criteria, the value obtained by students is 0 points.

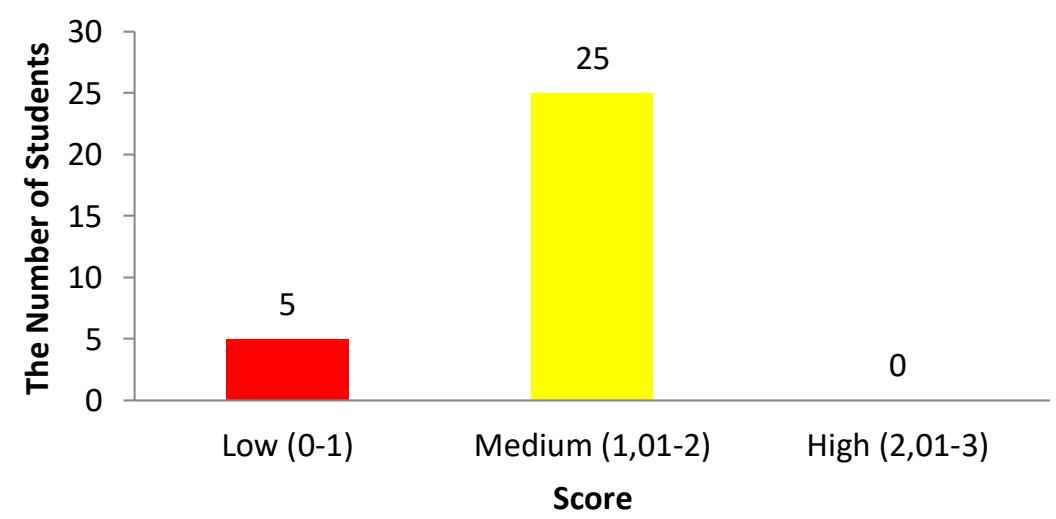

Figure 1. Result of students' problem-solving skills

Based on Figure 1 obtained, the value of problem-solving skills varies between one student with another. The value obtained can be seen that the number of students who score 
with medium criteria is 25 students and with a low criterion of 5 students. However, for high criteria, none of the students scored with these criteria. The value of problem-solving skills can be known based on the answer sheets that have been completed with the problemsolving criteria (A-C-C-E-S).

- Assess the problem (Identify the principles used in solving problems)

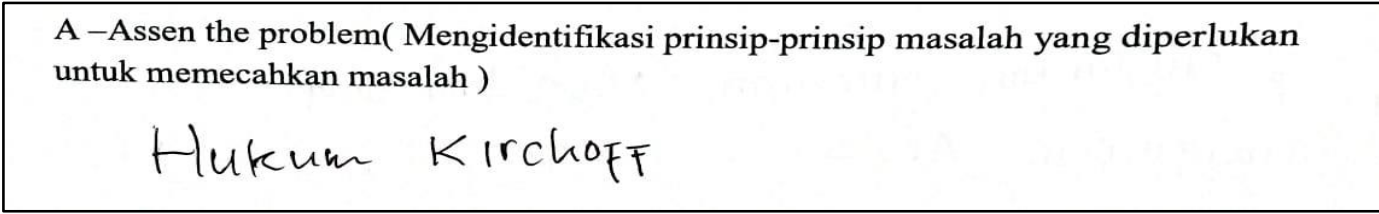

$A$-assess the problem (Identify the principle needed to solve the problem: find the voltage issued at the point $A B\left(V_{A B}\right)$ ).

Figure 2. Identify the principles used in solving problems

From Figure 2, it can be seen that the student's answers do not match the answers expected. In figure 1, students are expected to find the principles used in working on problems. However, students have not been able to explain the principles used in solving problems, students only explain Kirchhoff's Law, but the expected answers are Kirchhoff's first law and Kirchhoff's second law.

- Create a drawing (Translate words in the form of pictures or drawings that contain instructions in solving problems)

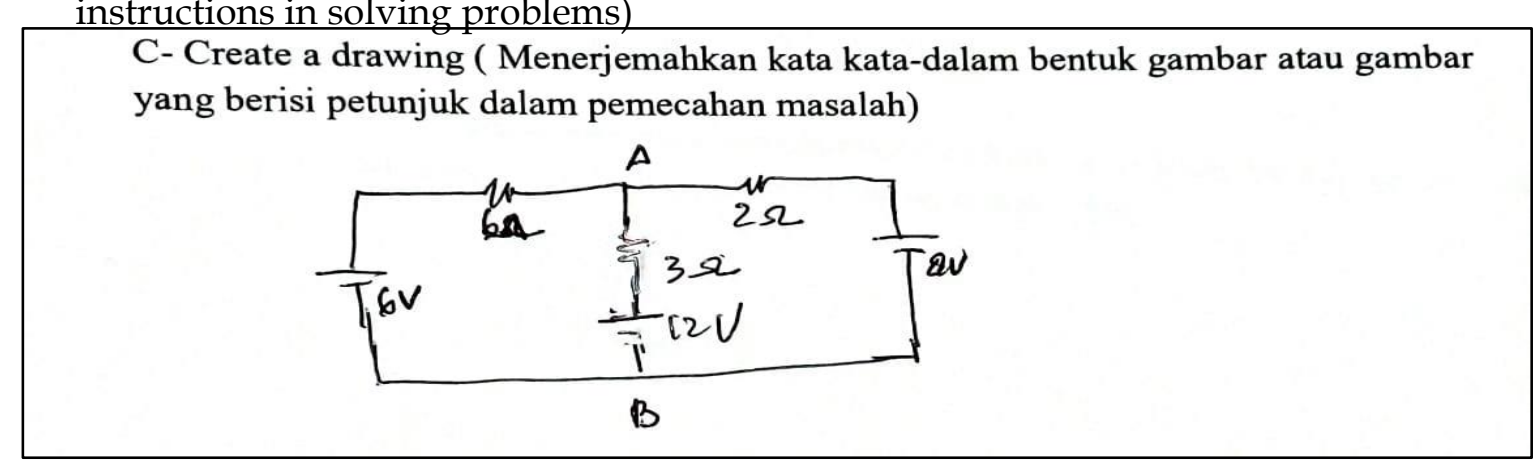

C-Create a drawing (Translate words in the form of pictures or drawings that contain instructions in solving problems)

Figure 3. Create a drawing

From Figure 2, it states that translating words in the form of pictures or drawings containing the work instructions by the problem and give the direction of the Loop. However, based on the answers of students, they did not solve following the directions of the current and did not give directions for Loop 1 and Loop 2 so that the circuit is difficult to understand and students difficult to solve problems.

- $\quad$ Conceptualize the strategy (outlines the steps that will be used in solving the problem)

C-Conseptualize the strategy( Menguraikan langkah-langkah yang akan digunakan dalam pemecahan masalah)

C-Conceptualize the strategy (Describes the steps used in solving the problem)

Figure 4. Conceptualize the strategy

From Figure 4, students are asked to outline the steps and strategies in solving problems. However, based on the answer sheet, students did not write answers to even formulas used. 
- Execute the solution (Apply the formula to solve the problem)

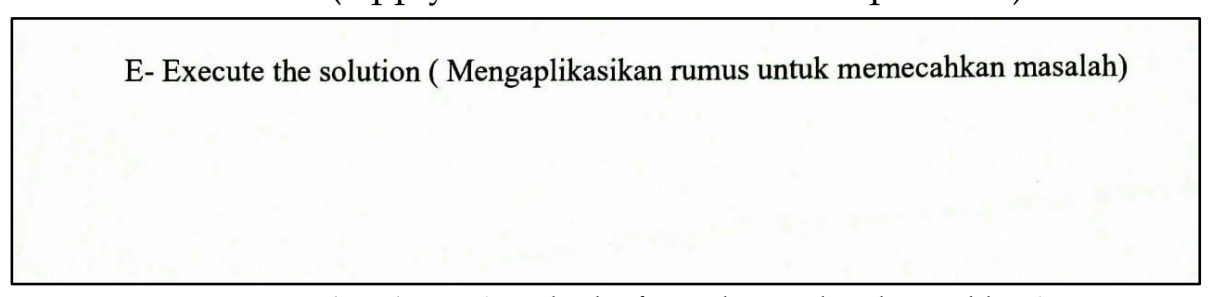

E-Execute the solution (Apply the formula to solve the problem)

Figure 5. E-Execute the solution

Figure 5 explained that students are asked to enter the numbers into the formula that has been chosen based on the problem to calculate the value of $V_{A B}$. However, at this stage, the students were not able to write the desired answers.

- Scrutinize your result (Are you sure about the answer)

\begin{tabular}{|l|}
\hline $\begin{array}{l}\text { S-Scrutinize yoyr result (Apakah anda yakin) } \\
-\quad \text { Yakin } \\
\text { Mengapa }\end{array}$ \\
\hline S-Scrutinize your result (Are you sure) \\
- Yes $\quad$ - Not Sure \\
Why?
\end{tabular}

Figure 6. Scrutinize your result

Figure 6 explained that students are asked to state their level of confidence through writing, accompanied by supporting theoretical reasons. However, based on the students' answers, they were just not sure without clear reasons.

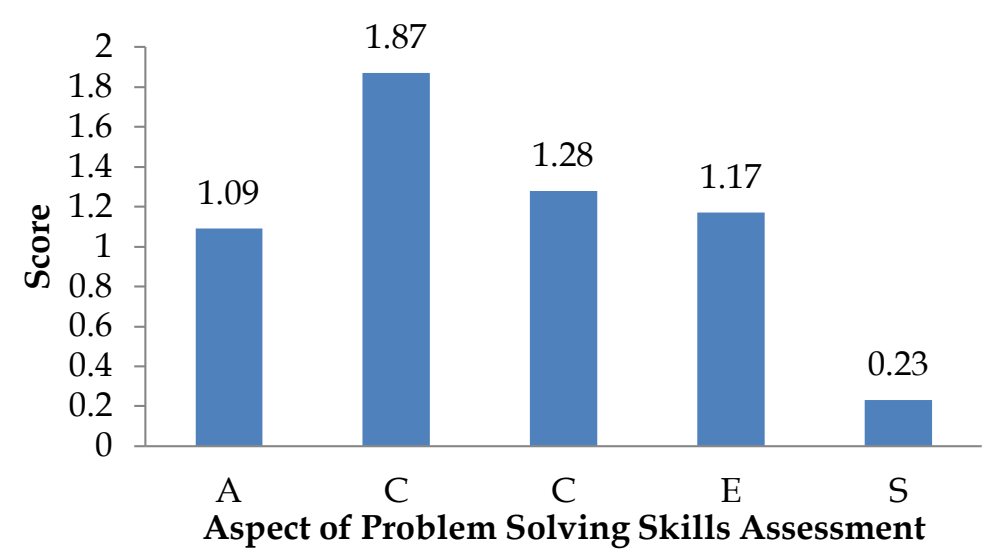

Figure 7. Aspect of assessment skills

From the Figure 7 of the relationship between indicators of physics problem-solving skills with the average value obtained by students can be seen if, the lowest value is found on the $S$ indicator (Scrutinize your result). Based on these values, it can be seen that students are 
not entirely sure of the answers given because in the process of their process many cheats and are assisted by their teachers without doing it themselves and most students do not make excuses that are following the concepts of physics they have learned. However, the average student could answer correctly on the C (Create a drawing) criterion. In indicator C (Conceptualize the strategy), many students have been able to describe the steps in solving a problem. In indicator E (Execute the solution), students could do it, but in the calculation, there were still many that are not careful enough so that the steps are correct, but the final results obtained were wrong.

Student Questionnaire Results

Table 1. Learners' responses to the questions

\begin{tabular}{lcc}
\hline \multicolumn{1}{c}{ Question } & Yes & No \\
\hline Did problem solver have been taught & 29 & 1 \\
Does problem-solving is important in physics & 30 & 0 \\
Have you ever an experiment on "Dynamic Electricity" & 5 & 25 \\
Have you ever experimented with PhET & 1 & 29 \\
\hline
\end{tabular}

Table 1 explained that student' responses to problem-solving, tracking students' problem solving is very important in solving physics. In SMAN 1 Driyorejo, students had been trained in problem-solving to do physics work. The result of the interviews showed that some students of SMAN 1 Driyorejo had not understood the scientific steps yet. However, as an alternative to substituting a school laboratory, one can use a virtual laboratory, namely, PhET. However, in the interview results, it was found that many students did not know about PhET, but after being shown, many students were interested in the application.

\section{Result of Interviews with Teachers}

The result of the interview, according to high school physics teacher problem solving is significant. However, during the problem-solving process, there are obstacles, namely when planting concepts in students. Besides, in the teaching and learning process, many students are more interested in the practice directly than using PhET (virtual laboratory). According to the teacher, students are more familiar in explaining using writing on the board than using a virtual laboratory or PowerPoint. However, when interviewed with students, many students are curious about the virtual laboratory (PhET). In the 4.0 era, we used technology in teaching and learning activities, one of which was by using a PhET (Virtual Laboratory).

\section{The Results of Review Articles}

The results of the article review to find out the influence of guided inquiry models in student learning.

Table 2. Result of review articles

\begin{tabular}{|c|c|c|c|}
\hline $\begin{array}{l}\text { Writer } \\
\text { (Year) }\end{array}$ & Sample & Research Design & Finding \\
\hline $\begin{array}{l}\text { Sipangkar et } \\
\text { al. (2018). }\end{array}$ & $\mathrm{N}: 68$ & $\begin{array}{l}\text { - Using the research } \\
\text { conducted is a quasi- } \\
\text { experimental design of } \\
\text { the Control Group } \\
\text { Pretest-Posttest Design. } \\
\text { - Manipulation variable: a } \\
\text { learning model }\end{array}$ & $\begin{array}{l}\text { - The value obtained in the experimental } \\
\text { class is higher than that of the } \\
\text { experimental class because, in the } \\
\text { experimental class, the student is directly } \\
\text { involved, so that motivates students. } \\
\text { - Student learning outcomes in the } \\
\text { experimental class } 64 \% \text { of students who }\end{array}$ \\
\hline
\end{tabular}




\begin{tabular}{|c|c|c|c|}
\hline $\begin{array}{l}\text { Writer } \\
\text { (Year) }\end{array}$ & Sample & Research Design & Finding \\
\hline & & $\begin{array}{l}\text { - Control variable: totally } \\
\text { of students, learning } \\
\text { material } \\
\text { - Response variable: } \\
\text { student learning } \\
\text { outcomes }\end{array}$ & $\begin{array}{l}\text { reach the minimum completeness criteria } \\
\text { (KKM). } \\
\text { - Student learning outcomes in the control } \\
\text { class } 47 \% \text { of students who reach KKM. } \\
\text { - Learning in the experimental class is used } \\
\text { the guided inquiry learning model is } \\
\text { increasing. }\end{array}$ \\
\hline $\begin{array}{l}\text { Maretasari } \\
\text { et al. (2012) }\end{array}$ & $\mathrm{N}: 64$ & $\begin{array}{l}\text { - Using scoring } \\
\text { techniques using pre- } \\
\text { test and post-test. } \\
\text { - Manipulation variable: } \\
\text { a learning model } \\
\text { - Control variable: } \\
\text { number of students, } \\
\text { learning material } \\
\text { Response variable: } \\
\text { student learning } \\
\text { outcomes and scientific } \\
\text { attitudes }\end{array}$ & $\begin{array}{l}\text { - Laboratory-based guided inquiry } \\
\text { influences the learning outcomes and } \\
\text { scientific attitudes of students. } \\
\text { - Scientific attitudes affect the } \\
\text { improvement of student learning } \\
\text { outcomes. }\end{array}$ \\
\hline $\begin{array}{l}\text { Amijaya et } \\
\text { al. (2018) }\end{array}$ & $\mathrm{N}: 68$ & $\begin{array}{l}\text { - Using quasi- } \\
\text { experimental research } \\
\text { with a nonequivalent } \\
\text { control group design } \\
\text { - Manipulation variable: } \\
\text { a learning model } \\
\text { - Control variable: } \\
\text { number of students, } \\
\text { material } \\
\text { - Response Variable: } \\
\text { Student learning } \\
\text { outcomes }\end{array}$ & $\begin{array}{l}\text { There is an increase in learning outcomes } \\
\text { of the experimental class, and the control } \\
\text { class from pre-test to post-test that is for } \\
\text { the experimental class increased by } 35.03 \\
\text { while the control class increased by } \\
26.16 \text {. } \\
\text { The guided inquiry learning model is } \\
\text { more effective than the conventional } \\
\text { model. }\end{array}$ \\
\hline $\begin{array}{l}\text { Partono } \\
(2015)\end{array}$ & $\mathrm{N}: 45$ & $\begin{array}{l}\text { - } \quad \text { This research uses } \\
\text { Pretest-Only Control } \\
\text { Design } \\
\text { - Manipulation variable: } \\
\text { a learning model } \\
\text { - Control variable: } \\
\text { teaching material } \\
\text { - Response variable: } \\
\text { student learning } \\
\text { outcomes }\end{array}$ & $\begin{array}{l}\text { - The comparison of the average learning } \\
\text { outcomes of students based on the } \\
\text { experimental class and the control class } \\
\text { is } 84.36>77.70 \text {. } \\
\text { - An indicator of the success of students in } \\
\text { completing the average problem } \\
\text { exercises in the experimental class was } \\
86.33 \% \text {, while the control class was } \\
76.67 \% \text {. } \\
\text { The inquiry learning model influences } \\
\text { the learning outcomes of students. }\end{array}$ \\
\hline $\begin{array}{l}\text { Pratiwia et } \\
\text { al. (2019) }\end{array}$ & N: 68 & $\begin{array}{l}\text { - Using a true } \\
\text { experimental research } \\
\text { design with a posttest- } \\
\text { only control design. The } \\
\text { sampling technique } \\
\text { used is a saturated } \\
\text { sampling technique. } \\
\text { - Manipulation variable: } \\
\text { a learning model } \\
\text { - Control variables: }\end{array}$ & $\begin{array}{l}\text { - The inquiry model has a positive effect } \\
\text { on student learning outcomes. } \\
\text { The guided inquiry learning model } \\
\text { based on authentic assessment gives a } \\
\text { positive influence of } 38.66 \% \text { on the } \\
\text { cognitive learning outcomes of students. } \\
\text { This is also reinforced by the increase in } \\
\text { the average initial value and posttest } \\
\text { value of the experimental class by } \\
\text { 15.04\%. In comparison, the control class }\end{array}$ \\
\hline
\end{tabular}




\begin{tabular}{|c|c|c|c|}
\hline $\begin{array}{l}\text { Writer } \\
\text { (Year) }\end{array}$ & Sample & Research Design & Finding \\
\hline & & $\begin{array}{l}\text { teacher, material, time } \\
\text { Response variable: the } \\
\text { result of the learning. }\end{array}$ & $\begin{array}{l}12.76 \% \text { and the experimental class have } \\
\text { very good criteria more than the control } \\
\text { class when viewed from the results of } \\
\text { psychomotor and affective domain } \\
\text { assessments of students. }\end{array}$ \\
\hline $\begin{array}{l}\text { Wahyuni et } \\
\text { al. (2016) }\end{array}$ & N: 76 & $\begin{array}{l}\text { - Using pre-test and post- } \\
\text { test control group } \\
\text { design } \\
\text { - Manipulation variable: } \\
\text { a learning model } \\
\text { - Control variable: totally } \\
\text { of students, material } \\
\text { - Respond variable: the } \\
\text { result of learning }\end{array}$ & $\begin{array}{l}\text { The result of learning students at the } \\
\text { time of the initial test and final test } \\
\text { students differed, there was an increase } \\
\text { between the control class with the } \\
\text { experimental class but a greater increase } \\
\text { in the experimental class. } \\
\text { It was shown that the physics learning } \\
\text { outcomes using the guided inquiry } \\
\text { learning model with the experimental } \\
\text { method affected compared to } \\
\text { conventional learning models. }\end{array}$ \\
\hline $\begin{array}{l}\text { Nurfausiah } \\
\text { (2016) }\end{array}$ & $\mathrm{N}: 60$ & $\begin{array}{l}\text { - Using design matching } \\
\text { pretest-posttest group } \\
\text { Manipulation variable: } \\
\text { a learning model } \\
\text { - Control variable: totally } \\
\text { student } \\
\text { - } \\
\text { Respond variable: the } \\
\text { result of learning } \\
\text { student }\end{array}$ & $\begin{array}{l}\text { The value of physics subjects taught with } \\
\text { guided inquiry models is very high, on } \\
\text { average, } 87.00 \text {. Moreover, the value } \\
\text { taught by the independent inquiry } \\
\text { learning model is in the very high } \\
\text { category, on average, 83.67. So that } \\
\text { teaching with the guided inquiry model } \\
\text { and independent inquiry model is no } \\
\text { different. }\end{array}$ \\
\hline $\begin{array}{l}\text { Nurmani et } \\
\text { al. (2016) }\end{array}$ & $\mathrm{N}: 72$ & $\begin{array}{l}\text { - Use quasi-experimental } \\
\text { with nonequivalent } \\
\text { control group design } \\
\text { - Manipulation variable } \\
\text { learning model } \\
\text { - Control variable: } \\
\text { learning material } \\
\text { - Respond variable: the } \\
\text { result of students } \\
\text { learning }\end{array}$ & $\begin{array}{l}\text { - The average value of the initial test } \\
\text { control class is } 46.12 \text {, and the } \\
\text { experimental class is } 49.09 \text {, with a } \\
\text { difference of } 2.97 \text {. These values are } \\
\text { categorized under the minimal } \\
\text { completeness criteria value and are } \\
\text { declared incomplete } \\
\text { - The value above will be a benchmark in } \\
\text { providing treatment } \\
\text { - After being given treatment, the average } \\
\text { value of physics learning outcomes for } \\
\text { the control class was } 66.75 \text { and for the } \\
\text { experimental class was } 74.47 \text {. } \\
\text { The guided inquiry learning model that } \\
\text { is applied to the experimental class has a } \\
\text { significant influence on student learning } \\
\text { outcomes compared to conventional } \\
\text { learning that is applied in the control } \\
\text { class. }\end{array}$ \\
\hline $\begin{array}{l}\text { Simbolon \& } \\
\text { Sahyar } \\
\text { (2015) }\end{array}$ & N: 76 & $\begin{array}{l}\text { - Using the quasi- } \\
\text { experiment } \\
\text { - Manipulation variable } \\
\text { learning model. } \\
\text { - } \quad \text { Control variable: totally } \\
\text { student and material. } \\
\text { - } \quad \begin{array}{l}\text { Respond variable: the } \\
\text { result of learning physic }\end{array}\end{array}$ & $\begin{array}{l}\text { The value obtained when using the } \\
\text { guided inquiry learning model based on } \\
\text { real experiments and virtual laboratories } \\
\text { is } 75.29 \text { while students who are taught } \\
\text { using the direct learning model get a } \\
\text { value of } 57.41 \text {. } \\
\text { There is a significant difference between } \\
\text { the learning outcomes taught by the } \\
\text { guided inquiry model based on real }\end{array}$ \\
\hline
\end{tabular}




\begin{tabular}{|c|c|c|c|}
\hline $\begin{array}{l}\text { Writer } \\
\text { (Year) }\end{array}$ & Sample & Research Design & Finding \\
\hline & & & $\begin{array}{l}\text { experiments and virtual laboratories } \\
\text { using direct learning models. }\end{array}$ \\
\hline $\begin{array}{l}\text { Zani et al. } \\
\text { (2018) }\end{array}$ & $\mathrm{N}: 24$ & 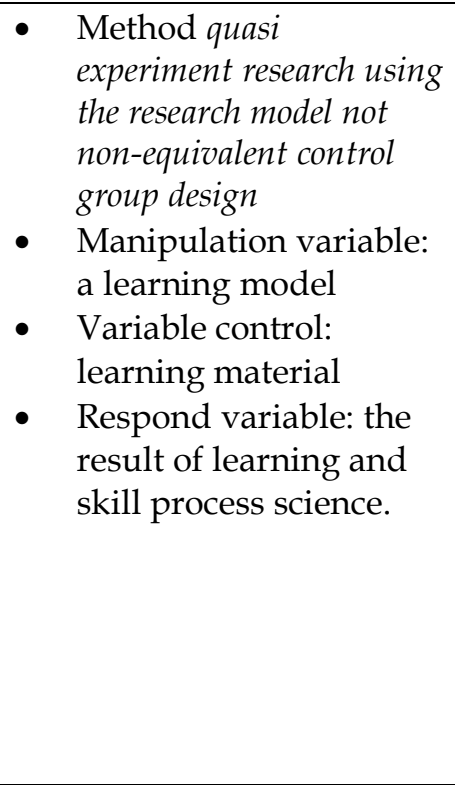 & $\begin{array}{l}\text { - The result of the test The Science Process } \\
\text { of Student Learning Skills on Static Fluid } \\
\text { Material from his pre-test and post-test } \\
\text { has increased. The improvement } \\
\text { obtained is as much as } 39 \% \text { in the control } \\
\text { class and as much as } 49 \% \text { in the } \\
\text { experimental class. } \\
\text { Student learning outcomes were } \\
\text { obtained from the pre-test and post-test } \\
\text { scores in the control class using } \\
\text { conventional learning models, the value } \\
\text { before treatment was } 38.5 \% \text {, and after } \\
\text { treatment was } 64.5 \% \text {. While the results of } \\
\text { pretest and posttest in-class } \\
\text { experiments with the application of the } \\
\text { guided inquiry model obtained a score } \\
\text { before treatment of } \\
44.8 \% \text { and after treatment, } 73.9 \% \text {. }\end{array}$ \\
\hline
\end{tabular}

\section{CONCLUSION}

Based on the data and analysis above, it can be concluded that the problem-solving skills in high school 1 Driyorejo are in the low and medium categories. Based on questionnaires and problem-solving skills tests based on the A-C-C-E-S components that have been done that problem-solving skills need to be trained by the teacher, especially in the completion of Physics subjects, especially on Dynamic Electric material. In research, students have never been invited to do practical work because laboratory facilities do not yet exist in schools and have not been or have never been introduced with a virtual laboratory, one of which is PhET. Efforts that can be made to improve problem-solving skills are to implement a guided inquiry learning model with PhET assistance. So hopefully, students can solve problems well based on indicators A-C-C-E-S.

\section{ACKNOWLEDGMENTS}

Thank you very much for SMAN 1 Driyorejo (Indonesia) has supported this research.

\section{REFERENCES}

Amijaya, L.S., Ramdani, A., \& Merta, I.W. (2018). Pengaruh model pembelajaran inkuiri terbimbing terhadap hasil belajar dan kemampuan berpikir kritis peserta didik. Jurnal Pijar MIPA, 13(2), 94-99.

Bogard, T., Liu, M., \& Chiang, Y.-V. (2013). Thresholds of knowledge development in complex problem solving: A multiple case study of advanced learners' cognitive processes. Educational Technology Research and Development, 61(3), 465-503.

Chang, C.-Y. (2010). Does problem-solving prior knowledge reasoning skills in earth science?: An exploratory study. Research in Science Education, 40(2), 103-116.

Gok, T. (2011). Development of problem solving strategy steps scale: Study of validation and reliability. Asia Pacific Education Researcher, 20(1), 151-161. 
Hamid, A. (2011). Belajar dan pembelajaran. Yogyakarta: Remaja Rosdakarya.

Majid, A. (2014). Pembelajaran tematik terpadu. Bandung: PT Remaja Rosdakarya Offset.

Maretasari, E., Subali, B. \& Hartono. (2012). Penerapan model pembelajaran inkuiri terbimbing berbais laboratorium untuk meningkatkan hasil belajar dan sikap ilmiah siswa. Unnes Physics Education Journal, 1(2), 28-31.

Markawi, N. (2013). Pengaruh keterampiln proses sains, penalaran, dan pemecahan masalah terhadap hasil belajar fisika. Jurnal Formatif, 3(1), 11-25.

Nurfausiah, S. (2016). Pengaruh model pembelajaran inkuiri terbimbing terhadap hasil belajar. Jurnal Pendidikan Fisika, 4(1), 10-13.

Nurmani, L., Doyan, A., Verawati, N.I.N.S.P. (2016). Pengaruh model pembelajaran inkuiri terbimbing terhadap hasil belajar fisika peserta didik. Jurnal Penelitian Pendidikan IPA, $4(2), 23-28$

Partono, L.N.R.K (2015). Pengaruh model pembelajaran inkuiri terbimbing terhadap hasil belajar fisika siswa kelas VIII SMP Negeri 4 Metro semester genap tahun pelajaran 2013/2014. Jurnal Pendidikan Fisika, 3(1), 65-72.

Pratiwi, K.F., Wijayati, F. N., Mahatmanti, W., \& Marsudi. (2019). Pengaruh model pembelajaran inkuiri terbimbing berbasis penilaian autentik terhadap hasil belajar siswa. Jurnal Inovasi Pendidikan Kimia, 13(1), 2337- 2348.

Putri D.A., Jamal, M.A., \& Misbah. (2016). Meningkatkan kemampuan pemecahan masalah siswa melalui model pengajaran langsung pada pembelajaran Fisika di Kelas X MS 4 SMA Negeri 2 Banjarmasin. Berkala Ilmiah Pendidikan Fisika, 4(3), 248-261.

Saparini, Wiyono, K., \& Ismet. (2018). Pengembangan lembar kerja mahasiswa berbasis inkuiri untuk melaksanakan praktikum secara virtual laboratory. Berkala Ilmiah Pendidikan Fisika, 6(1), 1-17.

Simbolon, D.H. \& Sahyar. (2015). Pengaruh model pembelajaran inkuiri terbimbing berbasis eksperimen riil dan laboratorium virtual terhadap hasil belajar fisika siswa. Jurnal Pendidikan dan Kebudayaan, 21(3), 300-315.

Sitika, L.M., Muharjito, M, \& Diantoro, M. (2015). Pengaruh problem based learning (PBL) berbasis guided inquiry (GI) terhadap kemampuan pemecahan masalah fisika ditinjau dari kerja ilmiah. Prosiding Pertemuan Ilmiah XXIXHFI Jateng \& DIY, 395-398.

Sipangkar, Y., Juliani, R., \& Siregar, A. (2018). Pengaruh model pembelajaran inkuiri terbimbing terhadap hasil belajar dan aktivitas siswa. Jurnal Pendidikan Fisika, 7(2), 103109.

Suparno, S, A. (2010). Membangun kompetensi belajar. Jakarta: Direktorat Jenderal Pendidikan Tinggi, Departemen Pendidikan Nasional.

Teodorescu, R., Bennhold, C., Feldman, G. \& Medsker, L. (2013). New approach to analyzing physics problems: A Taxonomy of introductory physics problems. Physics Review Physics Education Research, 9(1), 010103.

Wahyuni, R., Hikmawati, \& Taufik, M. (2016). Pengaruh model pembelajaran inkuiri terbimbing dengan metode eksperimen terhadap hasil belajar fisika siswa kelas XI IPA SMAN 2 Mataram tahun pelajaran 2016/2017. Jurnal Pendidikan Fisika dan Teknologi, 2(4), 164-169.

Zani, R., Adlim, \& Safitri, R. (2018). Penerapan model pembelajaran inkuiri terbimbing pada materi fluida statis untuk meningkatkan hasil belajar dan keterampilan proses sains siswa. Jurnal IPA dan Pembelajaran IPA, 2(2), 56-63. 
Corresponding Author:

Binar Kurnia Prahani

Department of Physics, Faculty of Mathematics and Natural Science,

Universitas Negeri Surabaya,

Jl. Ketintang, Surabaya 60231, Indonesia

Email: binarprahani@unesa.ac.id 